\title{
On Education Unbound from its Knowledge
}

\section{A.J. Bartlett}

...no-one ever made me say St Petersburg

Alain Badiou ${ }^{1}$

...white people go to school where they teach you how to be thick

The Clash ${ }^{2}$

I have always had 'school sickness'. I cannot cross the threshold of a teaching institution without physical symptoms ... of discomfort and anxiety. And yet it's true, I have never left school in general. I must suffer also from 'school sickness'.

Jacques Derrida ${ }^{3}$

\section{Preface}

For the conference to mark the thirtieth anniversary of Reading the Country, I was asked to speak on the question of education. My argument, following the work of Alain Badiou, is that the only form of real change is the production of some new truth in and for a given world. Such work is that of a subject, and the construction of a subject is the force of any education. Truths are antagonistic to and subtractive of knowledge; subjects are not reducible to individuals; and education is thus irreducible to known knowledge, opinion and the entire logic of interest. There is not and never has been any truth in the state other than as immanent exception to it. Education aims at what is universal, at what is for all. 'What is for all' presumes that a regime predicated on the flux of exploitation, competition and interest must truly change. If education is not about truth, it is about nothing 
but repetition - change (or 'modernisation'), such that there is no change at all. Repetition is movement's image. This version of real change, naturally antagonistic to the state, is also antagonistic to what is often supposed to be in opposition to it: in this case what Stephen Muecke presents in his work as the theory of nomadology. ${ }^{4}$ Indeed, it is possible to say that this theory of nomadology, despite its intent but intrinsic to its composition, and in concert with various modes of critique, has effected in the contemporary neoliberal state the means of its discourse; that, partially via the school and the academy as means of transmission, and via the cultural formations informed by these and without forgetting the knowledge effects of the predations of capital as lived experience, it has been inculcated as such. The basis of this conflation, I suggest, is a shared predicate in the disavowal of truths and subjects, or equality and the means of organisation it entails. For Muecke's Deleuze-inflected propositions, no such subjects exist; for the state, no such subjects must come to exist. When I speak of nomadology here, however, I speak only of the theory; I have nothing to say about Muecke's specific application or realisation of it. What I aim at, polemically, beyond the state of the educational situation, is education as real change, absolutely without inscription in the state, and as such universal: education for all such that it is 'what a people are capable of' and not 'what can be done to a people'; an immanent universality, invariant. In the way of the construction of such a thought it is perhaps truly 'nomadic', precisely insofar as no a priori conceit as to knowing the limits of knowledge, the horizons of being or of subjective capacity directs the traverse, which is to say, the orientation of all to what is real for it.

\section{Constructing corruption anew}

Plato's contention in the Laws continues to resonate: 'if at any time education becomes corrupt, but can be put right again, this is a lifelong task which everyone should undertake to the limit of his strength'. ${ }^{5}$ For Plato, sophistry named this corruption, consisting in the nexus of exchange between knowledge and money, the form of the state and the youth. What the sophists taught, for money - very good money in some caseswas the knowledge of the state: better and worse, success 
and failure, technique. Sophistry sells whatever works to this end, without discrimination as to its good-selling whatever sells - teaching the youth that the interests of the state are in its interest. Knowledge and the state are synonymous, implicative. Socrates names the procedure for not knowing this knowledge.

Today, more completely than at any other time, education is reduced to being the training ground for good state subjects: as so many policy and curriculum documents, no less than course descriptions, excitedly attest. The rhetoric of employability, job readiness, adaptation, flexibility, resilience and so on - all of which see the subject in no other terms than that of 'human resources'- that great concept of Stalin no less - permeates and determines the educational discourse of the so-called West and those determined to follow its 'lead'. The educational systems of the latter-ex-Soviet as much as postcolonial-have been humanitarianly-intervened-on in the name of the good of education. Such a good requires, the World Bank tells us:

flexible and nimble institutions and policy frameworks that can adapt to rapid change, and a creative and entrepreneurial private sector that can exploit new opportunities that emerge from that rapid change. Thus creating a society of skilled, flexible and creative people, with opportunities for quality education and life-long learning available to all, and a flexible and appropriate mix of public and private funding. ${ }^{6}$

This is the good(s) the Western nomad trades on in its interest, repeated in policy documents and faculties of education everywhere without remorse. As Marx noted: 'Whenever it comes across evil it attributes it to its own absence, for, if it is the only good, then it alone can create the good.'

The nineteenth-century dreams of figures like J.K. Shuttleworth - tasked with getting state education off the ground in the United Kingdom - for an education that 'promot[es] the diffusion of that knowledge among the working classes which tends beyond anything else to promote the security of property, an appreciation of free trade and the 
maintenance of public order' are in our age decidedly real. ${ }^{8}$ In his excellent but subtle book, Rethinking the School, Ian Hunter celebrates Shuttleworth as bringing to his task 'a non-ideological pragmatism'. 9

Shuttleworth's work as chief pedagogue and saviour of the poor had already caught Marx's attention. Among the pointed critiques, and with a sharper eye for irony than Hunter perhaps, he situated the type: the pedagogue takes his place among, and in the service of, the various social reformers - 'economists, philanthropists, humanitarians, improvers of the conditions of the working class, organisers of charity, members of societies for the prevention of cruelty to animals, temperance fanatics, hole and corner reformers of every imaginable kind'. ${ }^{10}$ Each, by these very 'socialist' means (we'd say democratic today), seeks only to secure and conserve the continuation of the rule of capital.

Today, UNESCO documents re-present this same nonideological, mobile pragmatism in assigning the moniker Low Development Capacity to countries long ravaged by colonialism and capitalism concurrently. UNESCO obscures this history in its telling, lest it subtract, ironically, from the historical narrative of incapacity. This assignation means in effect that these countries qualify for (are now 'ripe for') educational intervention: the model education being that which makes their country capitalism-ready, in the same way students today as a priority are to be rendered job-ready.

A single example of a global complicity:

We have devised the UNESCO Capacity Development for Education for All program (CapEFA) for this purpose, pooling funding from different donors to help countries improve the effectiveness of their educational systems. One example of the implementation of this scheme was Côte d'Ivoire, where the challenges included insufficient links between the labor market and the training availability, outdated curricula, and lack of quality data. ${ }^{11}$

The problem today is not that neoliberalism is trying to take over education, as so many critical pedagogues, uptight archeliberals and nineteenth-century-Cardinal-Newman-imitating 
gentlefolk idealists think: the problem today is that education is neoliberal. Neoliberalism is the contemporary form of the state. It is the knowledge of capital. It provides the norm by which reality is constructed, exactly what the cronies of the Mount Pelerin Society set out for it to be some seventy years ago and which they have achieved: 'a thoroughgoing reeducation effort for all parties to alter the tenor and meaning of political life: nothing more, nothing less'. Shuttleworth's dream of free trade for all in public schools is now the everyday knowledge of the school. As Naomi Klein among others points out, Chile après coup is the contemporary model for living this old dream. ${ }^{12}$

The globalised pedagogy of Mount Pelerin squares with the key idea that animates Emile Durkheim's brilliant study of the history of the school in France: 'that the forms and methods of didactic organization depend on the way in which, in a determined age, the general organization of knowledge is conceived, and above all on how the opening of knowledge towards thought itself is seen ...' 13

Hence in neoliberalism, neoliberalist pedagogies are embraced and deliriously reconciled as the 'knowledge economy': not simply knowledge for sale or reduced like all else to the commodity form, but knowledge as economy-economy, the law of the state qua household as all knowing and thus itself unknowable, which, as Agamben shows us, means we are under the administration of angels. ${ }^{14}$ What the "better angels of our nature' occlude, which is their one and only true job, is the opening to thought of this unknowable guarded by some God or other. In the case I am tracking here, as Plato demanded as the work of us all, what the current Angels of our flexible and flux-able nature occlude is the thought of education itself.

This observation of Durkheim also necessarily includes the contemporary critiques of this form of 'state education' including those mentioned-critical pedagogues, liberals and gentlefolk idealists - but not only them; and thus a further problem remains over for thinking education against the all-change market sophistry of today. I can only indicate the problem here: the great bulk of this critique, emerging out of the 1970 and 1980 - critiques of curriculum, institutional arrangements, the epistemological, psychological and political 
context and so on and lately, among the deluded enthusiasts of the techno-giscenti, who provide the edifying site of accusations as to the almost terroristic lack of educational innovation or 'disruption' - shares with the 'knowledge economy' an epistemological predicate: ostensibly that the subjective capacity to know is bound at the limit by some conception of the unknowable or inaccessible or ineffable or unsayable or indeterminate.

\section{Metaphysics, nomads, a queer sort of education}

Ostensibly, this lately Kantian-inspired-critique-becomecommonplace is a theology. In ancient times to traverse the unsayable was an impiety that was punishable by death. Socrates went down for just this; treating with the irrationality of diagonals and the capacity of slaves for truth (and mentioning where the money came from), and yet it seems to be the 'unsayable' seems to be the one stake our contemporary critics of all varieties, all anti-Platonists, won't wager!

Death as implacable horizon or the hermeneutic imperative of finitude - or in other terms, 'giving in' to our animal being or even the pieties of 'critique'-remains the horizon of so much contemporary discourse, saturating not so much thought itself (which always reserves the right to the infinite), but the representation of it in a form of knowledge which, despite or because of its finitist protestations concerning limits (the ineffable, unsayable, veiled, neumenon), is guilty of the highest conceit: of knowing, thereby, what can and cannot be known as knowledge. It's a totalising regime masquerading as the height of liberalist freedom - whose metaphysical name is potential. Of course liberalism has always been a masquerade, as Dominico Losurdo sets out for us in a most telling way. Its classical feature is to tell itself what it is not. Positive Psychology performs the same fiction anew, in university departments the world over.

Today the 'market', already a metaphor, a mark of the displacement of the real, is for us that master signifier which knows precisely what we do not and cannot know-this being the didactic of Mt Pelerin - and thus being good Kantian subjects, what must not be known. Hence as the totalising condition of all known knowledge the market cannot be 
thought; it marks the space of the ineffable limit for creatures like us and, just like the mind of God, we must only know it as our 'manifest destiny' and not presume to think it. Which is to say, to think what is true of it - exploitation, division in two examples - which is also to say, to think what-it-is-not for all. That way lay the camps, so goes the current pedagogicisation.

In the theoretical perspective Stephen Muecke deploys in Reading the Country, ostensibly and critically to think that which has not been thought before and, as such, that which might educate us anew, and deployed moreover to provide him a discourse in which to transmit this 'new' thought drawn from a specific encounter, he seems unfortunately to affirm this finitist predicate as constructive of this nomadology: a 'theory that recognises its limits, knowing that its object, always smarter than any subject, remains partially impenetrable'. ${ }^{15}$ (One may wonder what work 'partially' is meant to do here.)

He relies, as do Deleuze and Guattari, on this Kantian dogmatic to moreover claim that any notion of 'common purpose' is untenable-being false at the limit. Ineffable difference, which means in these terms the constancy of deterritorialisation has the day. Difference manifest is difference found. In other words, the empiricism available in Deleuze and Guattari is found on the ground in Reading the Country. Nomadology and what we might call the neoliberal sublime coincide at this juncture (this is not a new observation, but circulated already in the early 1970's when 'nomadology' took flight 'horizontally' as it were), of knowing what must not be known, of, ultimately, and in tune with the times or at least the theoretical times of western theory, committing a destitution of the subject. Thus they coincide not just in their hori-zonal conception of space but also in their metaphysics of the subject.

This destitution is not 'de-individualisation' or even the individualisation of communities of difference but de-subjectivisation: the impossibility of some collective, participative formation predicated on an indifference to differences, on some idea irreducible to any specified or determined body and to any determinative and classificatory schema of language. In short, the destitution of a subject predicated on what we are capable of here and now beyond such a reduction to the finitist 
categories of 'bodies and languages', identities and differences. This subject has been shamed into impossibility by charges of immodesty and impiety: impiety before the market, immodesty before our a priori determined limits, which, when we add the vitalist-empiricism, converts this knowledge into what is effectively a bio-logic of subjective incapacity. Thought, the very kernel of the subject, the wager that is its sole predicate is annulled in the knowledge that goes before it of this 'partial impenetrability', this living impossibility.

Purposefully vague but ideologically crucial conceptions of change, innovation or disruption predicated in an affective other-worldly vitality provide the very conditions of the constancy of this nomadic regime of knowledge: constant movement or innovation, and so, paradoxically, an anti-statist 'disruptive' conceit is its loudest most interminable refrain, its contemporary pedagogical force. The unsayable, ineffable etc., what remains over as a thoroughly un-actualised infinite potential, stands guarantee for the in-terminable multiplicity of appearances or knowledges, movements and 'disruptions', which the repetition of deterritorialisation requires. Another way to put this is as the 'free market in ideas', where everyone can choose their own 'truth' qua identity given precisely that nothing is truly true - nothing 'solid'. This is the triumph of the simulacra, wherein the economy of immutable difference is life itself - the beings of (non)being. And you cannot opt out.

To distinguish nomadology from capital - both of which 'commercialise this void' (of non-being) as the impossibility to truly decide - what we need to ask is what holds out against this, what point of indifference, what point of a new orientation? What in the education situation refuses the demand to not demand the impossible as real? Without holding to something un-deterritorialisable, nomadology can only be conceived as a clearing for what already exists and not an inventing of what can be: 'if the people do not have their own politics [education], they will enact the politics [education] of their enemies: political history abhors a void'. ${ }^{16}$ The great sophist of the ineffable multiple, Protagoras, already described this ineffable condition of human-being: 'It is impossible to judge what is not, or to judge anything other than what one is experiencing, and what one is immediately 
experiencing is always true.' But the catch is that this unactualised multiplicity whose being is movement-manifest as individual experience - is the logic of the state itself.

This nomadism as prescribed here is too much and not enough. It is movement sanctioned by the constancy of what is impossible for us, what is impossible to know. What is off limits is that this very bond between the logic of indetermination and the multiplicities of desire be itself cut and thus what is impossible in the moving image of knowledge that organises us pedagogically - we are all educated after all-is the truly new: not some laissez-faire fantasy, which is to return to the market-divine but the truly new as that-which-is for all. A subject is what holds to this - that truths are what a collective is capable of - which is (not) impossible. In other words, the state is incapable of truth, but this does not mean, as has long been assumed, that truths are thereby fictions of the state.

An education predicated on a limit or a horizon of the knowable - 'the pedagogy of the world as it is'17 - is, as Plato says, a queer sort of education: one that reduces to a mere utility function and, having a use, can be bought and sold depending on the difference currently demanded by the market. Education is currency. It presumes also, 'conceitedly' to use Plato's term of art, that there exists a knowledge, contradictory (as noted, the knowledge of the limit), off limits to thought and so (and clearly problematically for the concept) off limits to education. It knows that to un-know the state is impossible, as there is no such knowledge and it is this unknowability or this subjective incapacity that is taught. Today education, given over to the nomadic predations of state logic - there is nowhere it cannot go - is the taught knowledge of the lack of education. This is not a paradox but the logic of the systemic necessity to not hold fast. 'The solemn and sanctimonious declaration that we can have no knowledge of this or that always foreshadows some obscure devotion to the Master of the unknowable, the God of the religions or his placeholders.'18 We might call it the hidden curriculum.

To reiterate: this 'disastrous theme of our "finitude", 19 which licenses deterritorialisation as state form is the default knowledge of established states. It was already that of the great Protagoras, had a Kantian re-emergence-the thing 
in itself as critique of classical metaphysics - and received a Heideggerian impetus - the destitution of the subject as adjunct to this limit. We could even put it in Wittgenstinian terms: the limit of my knowledge is the limit of my world. Thus language, knowledge, existence, life and being, bound ineffably, constitute a reflexive a-subjective pedagogical matrix through the Kantianism of critique, the Heideggerian reflex, the 'linguistic turn', much of post-structuralism, deconstruction, so called post-modernism and as bio-nomadology, wedded as it is to the eternal flux over the production of the true. The internal oppositions we might productively find in this matrix, and indeed the critical force available there, turn nevertheless on a commitment to a singularly and fatally shared predicate.

Much of this, leaking into and then out of the humanities, finds itself re-presented (and it is this act of re-presentation that is critical) in policy and curriculum documents, in the faculties of education 'educating the educators', attesting less to an appropriation than to this shared constructivist predicate which its own critique has never broken down. It comes down to a single presumption: 'that which is not susceptible to being classified within a knowledge is not'. As Durkheim points out, with specific reference to education, to what is true for it, 'the recurrent and never fully solvable tension between thinking and knowledge is the rule rather than the exception'.20 In other words the thinking of education needs again to be unbound from its knowledge.

\section{Invariance: singular universal}

To institute a break, let me quote Alain Badiou, from the early 1970s:

Hand over education to those who got tired of antagonism, to all those who, after joining their fate to that of the workers, have since then come back to their prescribed place as intellectuals, and you will make the wish of state functionaries come true by keeping thought for the next two decades within the narrow confines of the usual course of affairs. It will be everyone for him or herself ... This is the surest road towards the worst. ${ }^{21}$ 
Let us take four episodes in this history of an antagonism, each of which decidedly sets out to avoid the worst: Plato, Saint Paul, Marx and Lacan. The polemical claim is that these four demonstrate the impossibility of education as a state form and it is this impossibility which is the basis of education being 'for all'. In other words and contra the nomadological predicate, universality has no relation to the state: the axiomatic for this, shared uniquely by each of my four examples, and in my terms, is that 'anyone has the capacity to not be known by the state'. Such an education manifests its subject; which is to say, and again contra nomadology, the state and the subject are irreducible.

The project of which these episodes are the integral part effectively re-analyses education with regard to its four component parts: epistemological, pastoral, political, psychological. The antagonism animated by this, if I may, re-reading of supposedly familiar country, situates, relative to Plato, Saint Paul, Marx and Lacan respectively, the truth of knowledge against the linguistic constructivism of state sophistry, a praxis of love or faring-well against the criterion and classification by law, 'the real movement which abolishes the present state of things' against the global and nomadic predations of bourgeois competition, and the desire of the subject against normalising discourses of 'change': 'adaptability' 'flexibility' and 'personality'.

In these four figures we see an education actively taking place. We see what it looks like in terms of invention, procedure and transmission: in terms of the break each affirms with established knowledge, the procedures they enact on the basis of this non-knowledge, the thought of this nonknowledge they establish and hold despite the vitality and utility of established knowledge and the new forms or genres of transmission they effect. All are or present as exiled and in some ways 'nomadic' figures relative to the state, but they are also figures of subjective re-composition, which is to say their traverse is also an orientation.

What is true for all is the discipline of the movement: what is nothing is what becomes everything, that is to say that the determined indeterminate is merely the what is nothing for the entirety of that situation. Across this divergence of instances 
or examples and in their discrete practice a formal invariance inheres and is demonstrable: this invariance provides us with the means to create its concept. We need to find in state-capitalist education (or the contemporary double-bind as set out above) that which it cannot assimilate to itself as the totality of knowledge: that which is invariant despite it. The argument is that this has been done before, or rather that this invariant exists and can be thought.

\section{To resume again}

The lover thinks more often of reaching his mistress than the husband of guarding his wife; the prisoner thinks more often of escaping than the jailer of shutting his door; and so, whatever the obstacles may be, the lover and the prisoner ought to succeed.

Stendhal 22

It is ridiculous to give summary to polemic but let me just note again what it forces into the scene of education. In the first place, that education is the site of a fundamental antagonism: this is because it can never rest assured as the knowledge of the state. It asks necessarily of this state of knowledge, this moveable feast of the knowledge economy, which supposes itself to be the limit of all. When the knowledge of the state is the state of knowledge education nowhere exists. Education always exceeds its limit and so begins again as an exception to it. This is the promise of education for all. And it is this immanent force that the knowledge of the state operates on in its interests. It idealises the promise and instrumentalises the procedure betraying, in a Lacanian sense, what is invariant to it. But this invariance insists and shows itself as unbound from the state and its limits, its metaphysics, its bio-logic. To insist on this invariance, which insists as what is not the knowledge of the state, and thus as what is truly education, is the force of the subject. The subject of education is the capacity to take, to produce, to invent a non-state form. The exceptional force of education is invariably to not know the state. This educated subject is the end of the subjective incapacity that the state cannot not teach: the teaching that the interests of the state are the interests of all and that there are no others 
is the intrinsic corruption of the state. The subject of education is necessarily the destruction of this subjective incapacity, the affirmative corruption of this corruption. Hence it is found nowhere in the state but is not impossible.

Education truly can only be the constructive destruction of this incapacity - which can only be un-educative given it stakes all its worth in a limit which is unthinkable for it. Paradoxically, perhaps, it is possible to see that in Reading the Country, in the construction of itself as an exceptional work, just such a subject insists and this despite the insistence of its own metaphysics that no such subject is possible. Indeed, the individuals that make up this subject are precisely deindividuated in the invention of this work as truly new, truly exceptional and for all. Something within the situation of the state that the state as such renders impossible, for it is made manifest as truly of that situation, this 'country'. The subject names this procedure of its invention, the construction of its form, which is at the same time the means of its transmission. The subject of education insists in its exception to the limit and as this ongoing procedure of which Reading the Country can be seen to be one more element. What is decisive is that we refuse to not read it there.

\section{Notes}

1 Alain Badiou, 'Of an Obscure Disaster: On the End of the Truth of the State', trans. B.P. Fulks, Lacanain Ink, vol. 22, 2003, pp. 58-89.

2 The Clash, 'White Riot', The Clash, CBS, 1977.

3 Jacques Derrida, 'A Madness Must Watch Over Thinking', Points: Interviews, 1974-1994, ed. E. Weber, trans. P. Kamuf, Stanford University Press, Stanford, 1995, p. 343.

4 Kim Benterrak, Stephen Muecke and Paddy Roe, Reading the Country, re.press, Melbourne, 2014, p. 23 passim.

5 Plato, Laws, trans. T.J. Saunders, in Complete Works, ed. J.M. Cooper and D.S. Hutchinson, Hackett, Indianapolis, 644a-b, 1997.

6 'Building Knowledge Economies: Opportunities and Challenges for EU Accession Countries. Final Report of the Knowledge Economy Forum "Using Knowledge for Development in EU Accession Countries", World Bank in cooperation with the European Commission the Organization for Economic Cooperation and Development the European Bank for Reconstruction and Development and the European Investment Bank Paris, 19-22 February 2002', May 2002, www.worldbank.org/eca/knowledgeeconomy. 
8 Harold Silver, Education and the English Radicals 1780-1850, Routledge \& K. Paul, London, 1975, pp. 96-7.

9 Ian Hunter, Rethinking the School: Subjectivity, Bureaucracy, Criticism, Allen and Unwin, Sydney, 1994.

10 Karl Marx and Friedrich Engels, The Manifesto of the Communist Party, Progress Publishers 1986, Moscow, p. 63.

11 UNESCO, Capacity Development for Education for All, 2011, http://unesdoc. unesco.org/images/o021/o02122/212262e.pdf

12 Naomi Klein, The Shock Doctrine: The Rise of Disaster Capitalism, Knopf, Toronto, 2007.

13 Emile Durkheim, The Evolution of Educational Thought, trans. P. Collins, Routledge and Kegan Paul, London, 1977.

14 Giorgio Agamben, The Kingdom and the Glory: For a Theological Genealogy of Economy and Government, trans. Lorenzo Chiesa, Stanford University Press, Stanford, 2011.

15 Benterrak, Muecke and Roe, p. 254.

16 Alain Badiou, 'The Fascism of the Potato', trans. B. Bosteels, in The Adventure of French Philosophy, London, Verso, 2012, p. 193.

17 Alain Badiou, Theory of the Subject, tran. B Bosteels, London, Verso, 2009. P. 302.

18 Alain Badiou, Logics of Worlds, trans. A. Toscano, London, Continuum, 2009, p. 535 .

19 Ibid.

20 Durkheim.

21 Badiou, Theory of the Subject, p. 181.

22 Stendahl, The Charterhouse of Parma, trans. J. Sturrock, Penguin, London, 2007. 